\title{
Altered Drug Metabolism and Transport in Pathophysiological Conditions
}

\author{
Adarsh Gandhi and Romi Ghose \\ Department of Pharmacological and Pharmaceutical Sciences, University of Houston, \\ United States of America
}

\section{Introduction}

\subsection{Overview of Drug Metabolizing Enzymes (DMEs) and transporters}

Drug metabolism can either lead to detoxification, bio-inactivation and/or elimination of the drug from the body. Metabolism can be broadly categorized into phases I and II. Phase I drug metabolizing enzymes (DMEs) primarily comprise of the Cytochrome (CYP) 450 family of enzymes. CYP3A4 is the most common isoform expressed in human liver and intestine accounting for $\sim 30-60 \%$ of CYPs (Nebert \& Russell, 2002) More than $50 \%$ of the currently marketed drugs are metabolized by CYP3A4 in humans (Guengerich, 1999). Phase II metabolism consists of conjugation reactions forming polar metabolites leading to enhanced excretion. Phase II reactions include glucuronidation (Uridine 5'-diphosphoglucuronosyltransferase, UGT) sulfation (Sulfotransferase, SULT), methylation (Methyltransferase), glutathione conjugation (Glutathione S-transferase, GST), etc. (Jancova et al., 2010; Meyer, 1996).

Drug transporters play a central role in the absorption, distribution, metabolism and elimination (ADME) processes of xenobiotics across the cellular barriers. They are broadly classified into uptake and efflux transporters which facilitate drug disposition in or out of the cells (Mizuno et al., 2003). Major transporters include, but are not limited to: multidrug resistant gene/P-glycoprotein (MDR/P-gp), multidrug resistance associated protein (MRP1$3)$, breast cancer resistance protein (BCRP), organic anion transporting peptides (OATPs) and organic cationic transporters (OCTs) (Mizuno et al., 2003; Mizuno \& Sugiyama, 2002).

\subsection{Altered drug metabolism and transport in pathophysiological conditions}

Several studies have shown that drug metabolism and transport is disrupted during diseases and altered pathophysiological conditions primarily due to reductions in gene expression of these enzymes and transporters (Aitken et al., 2006; Kato, 1977). The transcription factors such as nuclear factor-kB (NF-kB), CAAT enhancer-binding protein $(\mathrm{C} / \mathrm{EBP})$ or nuclear transcription factor E2-related factor 2 (Nrf2) have been shown to regulate DME and transporter gene expression in vivo and in vitro (Gonzalez \& Lee, 1996; Shen \& Kong, 2009; Zordoky \& El-Kadi, 2009). In addition to basal transcription factors, the xenobiotic nuclear receptors, pregnane $X$ receptor (PXR), constitutive androstane receptor $(\mathrm{CAR})$ heterodimerize with the central nuclear receptor, retinoid $X$ receptor (RXR) a to 
regulate the expression of DME and transporter genes (Chen et al., 2004; Goodwin et al., 2002; Kast et al., 2002; Xie, 2008). Furthermore, nuclear receptors such as peroxisome proliferator activated receptor (PPAR), liver $X$ receptor (LXR) or farsenoid $X$ receptor (FXR) can also regulate DME and transporter gene expression (Xie, 2008). The orphan nuclear receptor, hepatocyte nuclear factor (HNF) $4 \alpha$ can regulate the gene expression of PXR and CAR mediated xenobiotic induction of CYP3A4 (Tirona et al., 2003).

Altered drug metabolism can lead to adverse drug reactions which account for $\sim 10 \%$ of hospitalized cases (Deng et al., 2009; Maddox et al., 2010). However, due to underreporting, the actual incidences may be much higher (Lazarou et al., 1998., Pirmohamed et al., 2004). As early as 1960s, variations in drug metabolism were observed in patients or animals with diabetes (Dixon et al., 1961), cancer (Kato et al., 1963), hepatitis (Klotz et al., 1974; McHorse et al., 1974) or influenza (Kraemer et al., 1982). Changes in drug metabolism were also associated with a corresponding change in the pharmacodynamics (PD) of drugs (Dixon et al., 1961; Kato et al., 1968). These early studies prompted the researchers to study the alterations in DME and transporter gene expression and activity in pathophysiological conditions such as cancer, diabetes/obesity, rheumatoid arthritis (RA), non-alcoholic fatty liver disease (NAFLD) and cardiovascular diseases (CVDs) such as hypertension, heart failure, or stroke, etc. (Alkayed et al., 2002; Charles et al., 2006; Fisher et al., 2008; 2009a; 2009b; Thum \& Borlak, 2002). Overall, the readers of this chapter will benefit from the discussions of the changes in expression of DMEs and transporters, and pharmacokinetics/pharmacodynamics (PK/PD) of clinically relevant medications in different pathophysiological conditions.

\section{Infection and inflammation}

\subsection{Bacterial infections}

\subsubsection{Drug metabolizing enzymes}

Most of the studies on regulation on DMEs have been documented with gram-negative bacteria. Of clinical relevance, sepsis induced by cecal ligation and puncture (CLP) is the most frequently used model owing to its close resemblance in the progression and characteristics of human sepsis (Wichterman et al., 1980). In a CLP rat model, total hepatic microsomal CYP content and activities were significantly reduced (Godellas et al., 1995). Infection of pigs with the gram-negative respiratory pathogen, Actinobacillus pleuropneumoniae, led to decreased clearances of antipyrine, caffeine, and acetaminophen 24 $\mathrm{h}$ after inoculation. This was further supported by decreased microsomal metabolism of several CYP-dependent substrates (Monshouwer et al., 1995). Another widely studied gramnegative pathogen, Citrobacter rodentium, is a natural murine pathogen which produces similar colonic pathology on the intestinal cells of the host as seen after enteropathogenic Escherichia coli infections in humans (Higgins et al., 1999). The mRNA and protein levels of CYP4F18 and 2D9 were induced in a live mouse model of inflammatory bowel disease induced by C. rodentium (Chaluvadi et al., 2009). The rapid down-regulation of CYP2Cs and CYP3As after intraperitoneal (i.p) injection and CYP4As after oral injection of C. rodentium were quantitatively and qualitatively different, suggesting that the effects of oral infection are not due to bacterial translocation to the liver (Chaluvadi et al., 2009). 
Although, gram-positive infections account for more than $50 \%$ of the total community acquired infections (Martin et al., 2003), very few studies have linked the effects of grampositive bacteria on regulation of DMEs. It was shown that in patients suffering from grampositive bacteremia such as Pseudomonas or Staphylococcus infections, an increase in volume of distribution $\left(\mathrm{V}_{\mathrm{d}}\right)$ and dilution of antimicrobial agents in plasma and extracellular fluids may occur, which needs careful monitoring of the dosage regimen (Pinder et al., 2002). Listeriosis, caused by Listeria monocytogenes, is one of the most critical food-borne diseases in humans. L. monocytogenes induced CNS infection in rodents significantly down-regulated mRNA, protein and activity of hepatic CYPs (Garcia Del Busto Cano \& Renton, 2003).

The gram-negative bacterial component, lipopolysaccharide (LPS), and the gram-positive bacterial component, lipoteichoic acid (LTA), serve as sterile infection models by inducing inflammatory responses in animals (Ginsburg, 2002; Leemans et al., 2002). LPS can downregulate the expression and activity of key hepatic, intestinal and renal DMEs in several animal species such as mice, rats or rabbits (Ghose et al., 2008; Sewer et al., 1996). Interestingly, studies have that changes in CYP expression and activity is dependent on the route of administrate at same dose of LPS (Shimamoto et al., 1998). We recently showed that LTA significantly down-regulated the gene expression of several phase I and phase II DMEs in mice (Ghose et al., 2009).

\subsubsection{Drug transporters}

Changes in expression of drug transporters can have significant impact on the safety and efficacy of the drugs. LPS treatment of mice significantly down-regulated P-gp and Mrp2, major transporters involved in disposition of clinically relevant drugs such as colchicine, verapamil, daunorubicin, cyclosporin $\mathrm{A}$ and the abundant food-derived carcinogen 2amino-1-methyl-6-phenylimidazo[4,5-b]pyridine (PhIP) (Dietrich et al., 2001; Petrovic et al., 2007). LPS-treated mice had significantly lower hepatic P-gp (30\% of control) and increased P-gp expression in the kidney (140\% controls) (Hartmann et al., 2001; 2005).

\subsubsection{PK/PD studies}

As early as 1980 's, it was shown that vaccination with the bacillus Calmette-Guerin (BCG) decreased clearance of theophylline in human volunteers (Gray et al., 1983). Altered PK was observed in other bacterial infections induced by Streptococcus pneumoniae (decreased antipyrine clearance) or Mycoplasma pulmonis (increased Tilmicosin plasma levels) (Modric et al., 1998; Sonne et al., 1985). LPS injections in animals and humans altered PK parameters such as maximum plasma concentration $\left(C_{\max }\right.$ increase), area under the curve (AUC, increase), half-life $\left(\mathrm{T}_{1 / 2}\right), \mathrm{V}_{\mathrm{d}}$ and clearance (CL, decrease) of several widely prescribed medications such as cisplatin, antipyrine, theophylline, hexobarbital, gentamicin and vancomycin (Gous et al., 1995; Hasegawa et al., 1994; Ishikawa et al., 1990; Shedlofsky et al., 1994). PK changes of drugs during bacterial infection or inflammation can profoundly affect the PD as well. E.g. turpentine oil-injected mice had very high anti-tumor activity of gimatecan compared to the controls (Frapolli et al., 2010). On the other hand, several studies have shown that inflammation does not affect the PD of drugs. E.g. despite of very high plasma concentrations of the calcium channel blocker, verapmil, or potassium channel antagonists, sotalol or propranolol; no change in the PD was seen in inflamed animals (Guirguis \& Jamali, 2003; Kulmatycki et al., 2001; Mayo et al., 2000). The authors concluded 
this to be due to altered receptor-functioning or receptor-ligand binding exhibited by inflammation. Nevertheless, the above studies need further evaluations to delineate the disparities in altered drug metabolism caused by different bacterial infections or inflammation which has significant clinical implications for drug therapy in disease states.

\subsection{Viral infections}

\subsubsection{Drug metabolizing enzymes}

Viral infections can also stimulate the immune system releasing various inflammatory mediators from the immune cells (Mannering \& Deloria, 1986). A survey of the literature reveals numerous studies on the effect of viral infections such as mouse-adapted influenza virus (Corbett \& Nettesheim, 1973), Newcastle disease virus (Singh \& Renton, 1981), encephalomyocarditis virus (Renton, 1981), chronic active hepatitis and cirrhosis (Schoene et al., 1972; Wilkinson, 1997) and HIV infection (Lee et al., 1993) on alteration of gene expression and activity of DMEs and oxidative pathways in animals and humans. Decreased levels of hepatic CYP1A2 were detected in children suffering from upper respiratory tract viral infections during an influenza outbreak (Chang et al., 1978; Kraemer et al., 1982). With exceptions of CYP2D6 mRNA and CYP1A2 activity, other major CYPs such as CYP2C9, 2C19, and 3A4 in HCV-infected PXB mice (chimeric mouse with human hepatocytes) were comparable to the non-infected controls (Kikuchi et al., 2010). Recombinant adenovirus injections in Sprague-Dawley rats led to significant down-regulation of renal CYP2E1 and hepatic CYP3A2 and CYP2C11 expression and activity, and induction of CYP4A protein expression (Callahan et al., 2005; Le et al., 2006).

\subsubsection{Drug transporters}

A recent study showed that HIV-type 1 viral envelope glycoprotein gp120 decreased P-gp and Mrp expression levels in rat astrocytes (Ronaldson \& Bendayan, 2006). However, due to the fact that HIV infected patients are on highly active antiretroviral therapy (HAART) consisting of numerous drugs, both, induction and suppression of drug transporters in HIV infection are reported (Giraud et al., 2010). Polyinosinic/polycytidylic acid [poly (I:C)] is widely used as a model of in vivo viral-induced inflammation. Poly (I:C) can induce interferons (IFNs) and pro-inflammatory cytokines such as interleukin (IL)-6, IL-10, IL-12, and tumor necrosis factor (TNF)-a. A significant down-regulation of key maternal hepatic and placental drug transporters and their endogenous substrates was observed upon i.p injection of poly (I:C) in pregnant rats (Petrovic \& Piquette-Miller, 2010) However, Abcb1b (ATP-binding cassette sub-family B member 1) and Abcc3 (ATP-binding cassette sub-family C) were significantly induced. A recent study in PXB mice infected with hepatitis $C$ virus $(\mathrm{HCV})$ reported significantly higher expression of MRP4 and OATP2B1 and lower expression of OCT1 compared to non-infected mice (Kikuchi et al., 2010).

\subsubsection{PK/PD studies}

During the 1982 influenza B outbreak in King County, Washington, 11 children whose asthma had previously been controlled with a stable theophylline dose, developed theophylline toxicity on this same dose (Kraemer et al., 1982). These children had a significant decrease in CL and increase in $\mathrm{T}_{1 / 2}$ of theophylline. HIV infections could also 
lead to altered PK of levofloxacin and fluconazole (Goodwin et al., 1994; Tett et al., 1995). End-stage liver disease, which is largely the result of HCV infection, now accounts for up to $50 \%$ of deaths among persons with HIV-1 infection (Bica et al., 2001). A clinical study in HIV-HCV-coinfected patients showed significantly lower nelfinavir oral clearances in HIV+ and $\mathrm{HCV}+$ patients with and without cirrhosis compared to HIV+ and HCV-negative patients (Regazzi et al., 2005). This presses the need for therapeutic drug monitoring in individualizing nelfinavir dosage in $\mathrm{HIV}-\mathrm{HCV}$-coinfected patients. In addition, an increase in $\mathrm{AUC}$ and $\mathrm{C}_{\max }$ of several anti-retrovirals are reported in $\mathrm{HCV}$-infected patients with moderate liver impairment (Veronese et al., 2000; Wyles \& Gerber, 2005). Other studies have also shown significantly higher AUC of docetaxel and reduced glomerular filtration rate, suggesting changes in renal CYP in rats injected with the recombinant adenovirus expressing $\beta$-galactosidase (Le et al., 2006; Wonganan et al., 2009). On the contrary, significantly reduced $\mathrm{C}_{\max }$ and AUC of ceftiofur hydrochloride were observed in pigs infected with porcine reproductive and respiratory syndrome virus compared to the uninfected pigs (Tantituvanont et al., 2009).

\subsection{Mechanisms for altered drug metabolism in infections and inflammation}

Bacterial or viral infections lead to activation of Toll-like receptor (TLR) signaling pathway, which leads to the induction of pro-inflammatory cytokines, IL-1 $\beta$, IL- 6 and TNF- $\alpha$ in the immune cells. In the liver, TLRs are present on the cell surface of various immune cells (the resident macrophages or Kupffer cells) as well as the hepatocytes (Scott et al., 2009). Out of the 13 TLRs identified in mammals, TLR4 is activated by the gram-negative component, LPS, and TLR2 is activated by the gram-positive component, LTA (Aliprantis et al., 1999; Takeuchi et al., 1999). We and others have shown down-regulation of Cyp3a11 and P-gp in LPS sensitive TLR4 wild type (C3HeB/FeJ) mice could not be detected in TLR4-mutant (C3H/HeJ) mice (Ghose et al., 2008; Goralski et al., 2003; 2005). Recent data from our lab showed that down-regulation of gene expression of key hepatic phase I and phase II DMEs in TLR2 ${ }^{+/+}$mice by LTA was blocked in TLR2-/- mice (Ghose et al., 2009). We also observed that LTA down-regulated Mrp2, had no effect on Mrp3 and induced Mdr1b expression. Although, most of the studies have cited the role of Kupffer cell-derived TLRs in hepatic drug metabolism, we and others have also shown that LPS or LTA treatment of primary mouse hepatocytes can directly affect the DMEs via TLRs present on the hepatocytes, independent of cytokines (Ferrari et al., 2001; Ghose et al., 2011a). TLR-mediated signaling is initiated by the down-stream adaptor protein, Toll-interleukin 1 receptor domain containing adaptor protein (TIRAP) (Kagan \& Medzhitov, 2006; O'Neill \& Bowie, 2007). We showed that TIRAP was involved only in TLR2-mediated regulation of DME and transporter genes (Ghose et al., 2011a), and not by TLR4 (Ghose et al., 2008).

Cytokines are involved in alteration of DMEs and transporters in vitro (Barker et al., 1992; Muntane-Relat et al., 1995). LPS-treatment of primary rat cocultures of hepatocytes and Kupffer cells significantly suppressed phenobarbital-mediated induction of CYP2B1 (Milosevic et al., 1999). This decrease was associated with a 5-fold induction in TNF-a released from the Kupffer cells in cocultures. In vitro studies with cytokine-treated rat or human hepatocytes led to decreased expression and activity of several drug transporters including efflux pumps such as P-gp, MRP2, 3 and 4, and BCRP, sodium-taurocholate cotransporting polypeptide (NTCP), a major sinusoidal transporter handling bile acids, 
uptake transporters such as OATP-B, OATP-C, and OATP-8 (Diao et al., 2010; Le Vee et al., 2008; Lee \& Piquette-Miller, 2003; Sukhai et al., 2000; Vee et al., 2009).

However, recent evidence suggests cytokines may not be playing a major role in regulation of DMEs. Earlier studies in TNF- $\alpha^{-/-}$and IL-6 $/ /$knockout mice revealed that DMEs were still down-regulated (Warren et al., 1999; 2001). A recent study by Kinloch et al in TNFR1-/-, IL1R1-/- and Kupffer cell depleted mice showed that only TNF-a, but not IL-1 $\beta$ and Kupffer cells, was involved in regulation of CYP3A11 and 3A25 oral C. rodentium infection (Kinloch et al., 2011). In addition, we showed that although down-regulation of DMEs was blocked in LTA-treated TIRAP-/- mice, hepatic cytokine gene expression remained unchanged (Ghose et al., 2011a).

Nitric oxide (NO), released from macrophages and hepatocytes during inflammation is also known to regulate DMEs (Morris \& Billiar, 1994). However, contrasting results have been reported for the role of $\mathrm{NO}$ in regulation of DMEs in cytokine-treated primary rat hepatocytes (Carlson \& Billings, 1996; Sewer \& Morgan, 1997). IL-1 $\beta$ and TNF-a-mediated down-regulation of CYP protein was NO dependent, but not in IL-6 mediated downregulation (Carlson \& Billings, 1996). NO was also shown to regulate the suppression of UGT activities in cytokine-treated hepatocytes (Monshouwer et al., 1996).

Several studies have shown that inflammation-mediated activation of NF-kB plays a significant role in down-regulation of DMEs (Abdulla et al., 2005; Gilmore, 2006; Ke et al., 2001). NF-kB can either indirectly regulate CYP gene expression through mutual repression between NF-kB and nuclear receptors, or can directly regulate CYP gene expression through binding to NF- $\mathrm{KB}$ response element in the promoter region of CYP genes (Pascussi et al., 2003). Interaction of NF-kB with nuclear receptors during pathophysiological conditions can alter expression of DMEs (Gu et al., 2006). Inflammation-mediated activation of mitogen activated protein kinase (MAPK), c-Jun-Nterminal kinase (JNK), also regulates nuclear receptors and DMEs (Adam-Stitah et al., 1999; Yu et al., 1999). Recent experiments in human gastric carcinoma and pancreatic carcinoma cell lines suggested a prominent role of JNK activation in down-regulation of P-gp protein expression (Zhou et al., 2006). However, further detailed studies using in vitro models such as cell lines or primary hepatocytes, and specific inhibitors of these cell signaling components will significantly contribute in understanding the mechanistic regulation of DMEs and transporters during inflammation.

We speculate that down-regulation of nuclear receptors during inflammation might be involved in regulating the gene expression of DMEs and transporters in animal models (Ghose et al., 2004, 2008, 2009; Synold et al., 2001). We also showed that down-regulation of nuclear receptors by LPS in TLR4 ${ }^{+/+}$or by LTA in TLR2 ${ }^{+/+}$mice was blocked in TLR4 mutant or TLR2-/- mice (Ghose et al., 2008, 2009, 2011a). On the contrary, mRNA and protein expression of several CYPs did not differ in PXR $/$ - or PPAR $/$ - mice treated with LPS (Richardson \& Morgan, 2005). Similarly, it was shown that PXR was least important in regulating several efflux and uptake drug transporters using PXR wild type or PXR null mice treated with LPS (Teng \& Piquette-Miller, 2005). However, the down-regulation of Bsep and Mrp2 mRNA in IL6-treated wild type mice was attenuated in the PXR null mice. Thus, involvement of nuclear receptors in inflammation-mediated regulation of DMEs and transporters may depend on the nature of the inflammatory stimuli. 


\section{Cancer}

\subsection{Drug metabolizing enzymes}

Owing to the fact that, most anticancer drugs have a very low or narrow therapeutic index, alteration of DMEs can lead to life-threatening adverse drug reactions or increased risk of treatment failure in patients undergoing chemotherapy. Decreased hepatic microsomal DME activity was detected in tumor bearing rats with Walker carcinosarcoma 256, where impaired metabolism of hexobarbital, strychnine and meprobamate was observed (Kato et al., 1963). Due to difficulties in obtaining human liver tissue from cancer patients, an Engelbreth-Holm-Swarm (EHS) sarcoma mouse model bearing transgenic CYP3A4/lacZ gene was developed (Charles et al., 2006). Reduced hepatic levels of the transgene-derived $\beta$ galactosidase, as quantified by o-nitrophenyl- $\beta$-D-galactopyranoside assay, and Cyp3a11 mRNA and protein was observed in these mice (Charles et al., 2006). Tumors derived from the surface of the ovary account for the vast majority of ovarian tumors (approximately $80 \%$ ). Altered gene expression ratio of CYP3A4/ABCB1 (P-gp) in cancer cells grown from epithelial ovarian tumors had significant contribution in altering docetaxel disposition (DeLoia et al., 2008). On the other hand, there was no significant correlation in CYP2C8/ABCB1 ratio suggesting that paclitaxel disposition may require additional critical gene products. The expression of several phase II DMEs was also characterized in EHS tumor-bearing mice (Charles et al., 2006). Out of 8 GSTs studied, six were reduced and two unchanged; SULT1A1 was increased while SULT2A1 and UGT2B5 were reduced, and no change was observed in UGT1A7. Tamoxifen remains the first-line targeted treatment for the estrogen receptor a-positive breast cancer patients and undergoes metabolism in the breast tissue which also consists of several DMEs (Williams \& Phillips, 2000). In a study examining the role of methylation patterns of genes responsible for tamoxifen metabolism, higher methylation rate of N-acetyl transferase-1 (NAT1), a phase II DME gene, was observed in human breast cancer tissues compared to control breast tissues (Kim et al., 2010).

\subsection{Drug transporters}

Changes in the genetic variability in clinical specimens as well as over expression of $A B C$ transporter family in tumors have been shown to play a critical role in multidrug resistance to several anticancer drugs (Hoffmeyer et al., 2000; Robinson et al., 1997; Yoh et al., 2004; Young et al., 1999). A recent study showed significant reductions in the mRNA levels of Mdr2, Mrp2, Mrp3, Ntcp, Oatp 2, bile salt export pump (Bsep), Bcrp, whereas Mdr1a and Oatp1 remained unchanged (Sharma et al., 2008).

\subsection{PK/PD studies}

Cancer-induced changes in the PK and PD profiles of several drugs have been documented since the late 1960s (Kato et al., 1968; Rosso et al., 1968, 1971). In a clinical study, the absorption rate constant, apparent $\mathrm{V}_{\mathrm{d}}$ and serum CL of penbutolol (antihypertensive drug) were significantly reduced in the cancer group (Aguirre et al., 1996). PD effect (reduction in heart rate) of penbutolol did not vary statistically in respect to baseline values in cancer patients (Aguirre et al., 1996). Reduction in the metabolism of omeprazole (CYP2C19 substrate) has also been observed in patients with advanced cancer (Williams et al., 2000). Reduced CYP3A expression resulted in $>2$ fold increase in the sleep time in tumor bearing 
mice receiving the widely used sedative-hypnotic, midazolam, (CYP3A specific substrate) (Charles et al., 2006).

\subsection{Mechanisms of cancer-mediated altered drug metabolism}

Since the 1800s, it was observed that chronic inflammation is frequently associated with the onset and progression of various cancers (Balkwill \& Mantovani, 2001). A strong association between cancer progression and induction of cytokines or acute phase reactive proteins in tumors is documented (Burke \& Balkwill, 1996; Burke et al., 1996; Naylor et al., 1993). E.g. EHS tumor-bearing mice had significantly higher circulating plasma levels of IL-6 (25 $\mathrm{pg} / \mathrm{ml}$ ) compared to the control mice (below detection limit). IL-6 mediated activation of JNK was also evident in EHS tumor-bearing mice, which again prompts the important role of JNK in regulation of DMEs. Studies have shown that TLR expression is enhanced in tumor cells lines (Yu \& Chen, 2008). However, the role of TLRs in alteration of DMEs and transporters in cancer has never been investigated.

The role of NF- $\mathrm{kB}$ activation in acute inflammation has been suggested in carcinogenesis (Karin et al., 2002; Lind et al., 2001). Cancer-mediated alteration of DMEs and transporters may possibly be regulated by over-expression of NF- $\mathrm{kB}$. A recent study highlighted the role of extra hepatic malignancies in down-regulation of PXR and CAR in tumor-bearing mice (Kacevska et al., 2011). This study prompts to link the reduction in nuclear receptors with altered drug metabolism in cancer. However, additional studies with nuclear receptor knockout animal models with tumors will help identify their direct role in regulation of DMEs and transporters. Overall, all these studies imply that tumor-mediated inflammation may play an integral role in drug response and toxicity of various anticancer agents.

\section{Diabetes and obesity}

\subsection{Drug metabolizing enzymes}

Another prevalent pathophysiological condition affecting millions of people in the world is the occurrence of diabetes and obesity. As per the latest statistical report, 366 million people in the world will have diabetes by 2030 (Wild et al., 2004). Dixon et al demonstrated that alloxan-induced diabetes decreased hexobarbital, chlorpromazine, and codeine metabolism in male rats (Dixon et al., 1961, 1963). Although, streptozotocin-induced diabetes in rats and hamsters significantly induced hepatic and renal CYP2E1 and 4A2 protein levels (Chen et al., 1996; Shimojo et al., 1993), suggesting altered metabolism of ketones and fatty acids in diabetes, hepatic CYP2E1 protein levels remained unchanged in streptozotocin-induced diabetic mice livers (Chen et al., 1996; Sakuma et al., 2001). A recent study showed differential effects of alloxan-induced diabetes on protein expression and activity of CYP2E1 (increased) and CYP2B4 (decreased) in rabbits (Arinc et al., 2005). Altered gene expression of DMEs in genetically obese zucker fatty rats (reduction in CYP2B1/2 and Mrp3) and $d b / d b$ mice (increase in CYP2B10) are also reported (Xiong et al., 2002; Yoshinari et al., 2006a). Studies have reported interesting results on DME gene and protein expression for different diet-induced obese (DIO) animal models. E.g. Although Cyp3a11 gene and protein expression were significantly reduced in both long term (12 weeks) and short term treatment (1 week) of high fat diet (HFD), Cyp2c9 gene expression was significantly reduced only in the short term HFD treatment (Yoshinari et al., 2006b). We recently showed that 
mRNA levels of the phase II DMEs (Ugt1a1, Sult1a1, Sultn) were reduced $\sim 30-60 \%$ in mice fed high-fat diet (HFD, 60\% kcal fat for 14 weeks) compared to low fat diet (LFD, 10\% kcal fat) mice (Ghose et al., 2011b). RNA levels of Cyp2e1 and Cyp1a2 were unaltered in HFD mice. These findings indicate that regulation of CYPs is dependent on the model of diabetes and obesity, and is tissue, isoform and species-specific.

\subsection{Drug transporters}

Streptozotocin treatment in rats increased hepatic levels of $M d r 2$, leading to increased phospholipid secretion into bile (van Waarde et al., 2002). Another study also showed that the hepatic expression of uptake transporters (Oatp1a1, 1a4, 1b2, 1a6, 2b1, and Ntcp) in diabetic mice decreased significantly compared to the wild type controls (Cheng et al., 2008). Our recent study showed no effect of high fat in DIO mice on gene expression of hepatic transporters (Mrp2 and 3, and Mdr1b) (Ghose et al., 2011b).

\subsection{PK/PD studies}

Obesity-associated alterations in phase II metabolism were reported in 1980's. E.g. clearances of oxazepam and lorazepam, widely used benzodiazepines and excreted as glucuronide conjugates, were significantly increased in obese patients (Abernethy et al., 1983). Similarly, increased metabolism of chlorzoxazone (CYP2E1 substrate) to 6hydroxychlorzoxazone was observed in obese individuals. This was attributed to increased CYP2E1 activity associated with obesity (O'Shea et al., 1994). Animal studies performed using a diabetes mellitus rat model (induced by alloxan or streptozotocin treatment) have reported altered PK of drugs such as acetaminophen, chlorzoxazone, theophylline, clarithromycin, furosemide, and methotrexate (Baek et al., 2006; Kim et al., 2005a, 2005b; Park et al., 1996, 1998; Watkins \& Sherman, 1992). Although, no changes in PD of atracurium were reported in obese animals compared to lean control (Varin et al., 1990), triazolaminduced sedation in obese humans increased significantly compared to normal weight men (Derry et al., 1995). We also observed similar disparities in the PD of midazolam, CYP3A substrate, (increased sleep time) and zoxazolamine, CYP2E1 substrate (no change) in DIO mice (Ghose et al., 2011b). This can be attributed to decrease in CYP3A and no change in CYP2E1 expression. Thus, the differential effects of obesity on PD of drugs may depend on the DME, or the drug or the target organ itself.

\subsection{Mechanisms of altered drug metabolism in diabetes/obesity}

The major pathophysiological manifestation in diabetes/obesity is characterized by lowlevel chronic and local inflammation, such as release or over expression of TNF- $\alpha$ and Creactive protein in adipose tissue (Hotamisligil et al., 1993; Wellen \& Hotamisligil, 2005). However, the role of inflammation in regulation of DMEs and transporters in diabetes/obesity remains unclear. Hormonal regulation of DMEs in diabetes/obesity has also been addressed before (Thummel \& Schenkman, 1990). Although an increase in mRNA or protein levels of CYP2E1 have been observed in obese patients (Lucas et al., 1998), db/db mice showed no such effects (Yoshinari et al., 2006a). This can possibly be due to hyperinsulinemia leading to a faster turnover (shorter CYP2E1 mRNA half-life) by insulin (De Waziers et al., 1995). Various studies have shown that phosphatidylinositol-3-kinase 
(PI3K) signaling, using PI3K inhibitors, wortmannin and LY294002, ameliorated insulinmediated decrease in CYP2E1 and phase II enzymes (a-GST) mRNA (Kim et al., 2006; Kim \& Novak, 2007; Woodcroft et al., 2002).

Interestingly, lower expression of CAR and CYP2B in obese Zucker rats and $\sim 2$ fold induction in obese and genetically diabetic mice $(d b / d b)$ on HFD (Xiong et al., 2002; Yoshinari et al., 2006b) were reported. This discrepancy in obese Zucker rats and $d b / d b$ mice in regulating expression profiles of CYPs and nuclear receptors can be explained by the difference in the position of mutation of leptin receptor gene (Chua et al., 1996; Lee et al., 1996). We recently showed that expression of PXR and CAR; and protein levels of RXRa were significantly reduced in HFD mice (Ghose et al., 2011b). Thus, a complex set of processes including but not limited to cytokines, nuclear receptors, insulin sensitization or downstream signaling molecules, may regulate DMEs and transporters in diabetes/obesity.

\section{Non-alcoholic fatty liver disease}

\subsection{Drug metabolizing enzymes}

Non-alcoholic fatty liver disease (NAFLD) is highly prevalent with an estimated world population between $14 \%$ and $24 \%$ being affected. NAFLD comprises of symptoms ranging from simple steatosis (fatty liver) to the more severe non-alcoholic steatohepatitis (NASH, fatty liver with infiltration of inflammatory cells) to progressive hepatic fibrosis and to cirrhosis (Reynaert et al., 2005). Alteration of hepatic CYP2E1 was first noted in humans with NASH (Weltman et al., 1998). Later studies have shown significant contribution of NAFLD (comprising of both, simple stage fatty liver as well as NASH) on expression and activity of DMEs in animals (Fisher et al., 2008, 2009a, 2009b). Similarly, in vitro studies in primary human or animal hepatocyte cell cultures from steatotic or non-steatotic livers showed a profound impact of steatosis on the metabolic functionality of hepatocytes (Donato et al., 2007; Fisher et al., 2004; Gomez-Lechon et al., 2004). Significant reductions in CYP1A2, 2C9, 2E1 and 3A4 activities in fat-overloaded hepatocytes were observed compared with control hepatocytes obtained from the same liver sample (Fisher et al., 2008).

\subsection{Drug transporters}

Decreased mRNA and protein expression of uptake transporters such as NTCP, OATP1a1, 1a4, $1 \mathrm{~b} 2$ and 2b1; and OAT 2 and 3 were observed in NAFLD (Fisher et al., 2009a).

\subsection{PK/PD studies}

Studies have shown interesting results with acetaminophen (APAP) PK in rats and humans with NAFLD. Children with NAFLD had significantly higher concentrations of APAPglucuronide (APAP-G) in serum and urine compared with controls, with no significant differences in PK of APAP among the 2 groups (Barshop et al., 2011). Another study showed that biliary concentrations of APAP-sulfate (APAP-S), APAP-G, and APAP-glutathione were reduced in MCD (methionine- and choline-deficient) rats (Lickteig et al., 2007a). However, plasma levels of APAP-G were also elevated in MCD rats, similar to that observed in children (Barshop et al., 2011). A clinical study evaluated the effect of NAFLD on PK of silymarin (Schrieber et al., 2008). The $\mathrm{AUC}_{0-24 \mathrm{~h}}$ for the sum of total silymarin flavonolignans was $\sim 3-4$ fold higher in patients with NAFLD $(\mathrm{p}<0.03)$, compared with healthy volunteers. 


\subsection{Mechanisms of altered drug metabolism in NAFLD}

Several mechanisms have been proposed for the effect of NAFLD on altered drug metabolism. Deposition of fat in human hepatocytes can lead to a marked impairment in CYP mRNA and activity (Donato et al., 2006). Fisher et al observed intense staining for IL-1 $\beta$ in steatotic livers, indicating that experimental steatosis and NASH results in increased hepatocellular inflammation (Fisher et al., 2009a). Studies have shown ambiguous results on expression of nuclear receptors and transcription factors in NAFLD (Fisher et al., 2009b; Hardwick et al., 2010; Lickteig et al., 2007b). Except for PXR, which was significantly increased by 1.4 fold, the other nuclear receptors (AhR, CAR, PPARa and Nrf2) were not altered (Fisher et al., 2008). Therefore, various factors need to be taken into account for improved pharmacotherapy in patients with NAFLD.

\section{Cardiovascular disorders}

\subsection{Drug metabolizing enzymes}

CYPs in humans are responsible for metabolizing a large number of cardiovascular medications, including $\beta$-blockers, calcium channel blockers and angiotensin receptor antagonists (Abernethy \& Flockhart, 2000). Alteration in DMEs could be of particular clinical relevance in patients with heart failure because these patients take more than 10 medications on average. Although, not detected in the normal human heart, failing hearts expressed CYP11B1 and 11B2 (Young et al., 2001). Surprisingly, an up-regulation in CYP2J2, 1B1, 2E1, 4A10 and 2F2 gene expression was reported in the failing heart (Tan et al., 2002). Increased cardiac CYP11B2 mRNA was associated with increased myocardial fibrosis and the severity of left ventricular dysfunction in patients with heart failure (Satoh et al., 2002). It was shown that the production of testosterone metabolites, including dihydrotestosterone and androstenedione, was significantly increased in hypertrophic human hearts (Thum \& Borlak, 2002). Transient ischemic attacks (TIA) are risk factors for strokes. A recent study showed that cerebral infarct size was reduced in TIA-preconditioned animals and CYP2C11 mRNA and protein were coincidentally increased in the brain after experimentally induced TIA (Johnston, 2004). Genetic polymorphisms of DMEs are commonly associated with heart failure and hypertension (Kivisto et al., 2005). E.g. a study in Japanese subjects reported that CYP2C9 wild type carriers had lower systolic blood pressure after losartan (metabolizes to the active metabolite EXP3174) therapy than poor metabolizers (Sekino et al., 2003).

\subsection{Drug transporters}

A recent study demonstrated a selective disease-dependent regulation of the high-affinity carnitine transporter, OCTN2, in patients with dilated cardiomyopathy, whereas the other OCT(N)s were unaffected (Grube et al., 2011).

\subsection{PK/PD studies}

It was shown that lidocaine plasma clearance was significantly decreased in patients with cardiac failure and this was associated with decreased liver blood flow (Thomson et al., 1971). Another group also observed reduced plasma clearance of lignocaine in patients suffering from myocardial infarction without cardiac failure (Prescott et al., 1976). Thus, the 
mounting evidence for the effect of CVDs on DMEs and transporters needs to be extended for further PK/PD studies.

\subsection{Mechanisms of altered drug metabolism in CVDs}

Failing or hypertensive hearts are susceptible to infiltration by pro-inflammatory cytokines and reactive oxygen species induced by stress (Fliser et al., 2004). Studies have shown that increased circulating levels of TNF- $a$ and IL-6 in patients with congestive heart failure were inversely proportional to CYP2C19 and CYP1A2 activity (Frye et al., 2002). Similarly, downregulation of OCTN2 expression in patients with dilated cardiomyopathy inversely correlated with cardiac CD3 ${ }^{+}$T-cell count (Grube et al., 2011). In addition, cardiac cytokine release may affect OCTN2 expression during cardiomyopathy associated with inflammation.

\section{Rheumatoid Arthritis (RA)}

\subsection{Drug metabolizing enzymes}

Rheumatic diseases are estimated to affect up to $1.1 \%$ of the world's population (Harris, 1980). Various studies have shown that gene expressions of DMEs are altered in adjuvant arthritis (AA) rats (Achira et al., 2002b, 2002c; Projean et al., 2005). Similarly, activities of CYP3A were significantly decreased in AA rats compared to control rats (Uno et al., 2007).

\subsection{Drug transporters}

Decreased activity of hepatic P-gp in the isolated perfused liver of AA rats was reported (Achira et al., 2002c; Uno et al., 2007). Decrease in P-gp activity corresponded with the decreased levels of Mdr1a mRNA and P-gp protein in AA rats.

\subsection{PK/PD studies}

PK/PD changes such as elevated plasma levels of acebutolol, cyclosporin A, propranolol and prolongation of sleep time with pentobarbital were observed in AA rats compared to normal rats (Dipasquale et al., 1974; Piquette-Miller \& Jamali, 1992, 1993; Shibata et al., 1993). Based on these early observations, recent studies have also shown altered PK of methotrexate, T-5557 (novel anti-inflammatory agent) and doxorubicin in AA animals (Achira et al., 2002a, 2002b; 2002d). Although, a significant increase in the plasma concentrations of verapamil in rats and humans with underlying arthritis were reported, there were no changes in the PD of verapamil (prolongation of PR interval) (Mayo et al., 2000; Sattari et al., 2003). This discrepancy was then attributed to a decrease in the receptorligand affinity in inflammation (Laporte et al., 1998; Shore et al., 1997).

\subsection{Mechanisms of altered drug metabolism in RA}

AA animal models represent a systemic inflammatory disease with bone and cartilage changes similar to those observed in RA (Williams et al., 1992). Down-regulation of hepatic P-gp in AA rats was attributed to elevated levels of cytokines such as TNF- $a$ and IL-6 but not IL-1 $\beta$ (Philippe et al., 1997). Similarly, increased plasma concentrations of drugs in AA 
rats correlated with increased serum TNF-a level (Sattari et al., 2003). Several in vitro and in vivo studies have shown up-regulation of NF-kB in RA and osteoarthritis (Handel et al., 1995; Mor et al., 2005). It was recently demonstrated that PXR and CAR expression in small intestine was decreased in arthritis (Kawase et al., 2007b). In another study, bilirubin elimination was significantly decreased in collagen-induced arthritis (CIA) rats compared to normal rats (Kawase et al., 2007a), which was attributed to decreased expression of CAR in CIA rats. Thus, overall these studies imply that inflammatory pathways may be involved in the regulation of DMEs and transporters in arthritis.

\section{Conclusion}

A common theme of this chapter is that a multiplex of mechanisms are responsible for alterations of DMEs, transporters and PK/PD of drugs in different pathophysiological conditions. It is well-established that changes in gene expression of enzymes and transporters can lead to disruption in drug disposition in altered pathophysiological conditions including infection/inflammation, cancer, obesity, CVD, rheumatoid arthritis, etc. Studies show that induction of inflammatory mediators is an underlying factor common to all these pathophysiological conditions and may contribute to altered drug disposition in disease states. In addition, the generally accepted role of cytokines in alterations of DMEs and transporters needs further evaluation. We have established the involvement of Toll-like receptor signaling pathway in the regulation of DMEs and transporters, and our studies point to the role of cytokine-independent pathways in the liver. The role of transcription factors and nuclear receptors in the regulation of DMEs and transporters in disease states need further investigation. There is an urgent need to develop models for delineating the roles of individual inflammatory mediators or nuclear receptors in altered drug disposition in disease states. Understanding alterations of drug disposition in disease states is critical in predicting and preventing undesirable effects of clinically-relevant medications.

\section{References}

Abdulla, D.; Goralski, K. B.; Del Busto Cano, E. G. \& Renton, K. W. (2005). The signal transduction pathways involved in hepatic cytochrome $\mathrm{P} 450$ regulation in the rat during a lipopolysaccharide-induced model of central nervous system inflammation. Drug Metab Dispos 33 1521-1531.

Abernethy, D. R. \& Flockhart, D. A. (2000). Molecular basis of cardiovascular drug metabolism: implications for predicting clinically important drug interactions. Circulation 101 1749-1753.

Abernethy, D. R.; Greenblatt, D. J.; Divoll, M. \& Shader, R. I. (1983). Enhanced glucuronide conjugation of drugs in obesity: studies of lorazepam, oxazepam, and acetaminophen. J Lab Clin Med 101 873-880.

Achira, M.; Totsuka, R.; Fujimura, H. \& Kume, T. (2002a). Decreased hepatobiliary transport of methotrexate in adjuvant arthritis rats. Xenobiotica 32 1151-1160.

Achira, M.; Totsuka, R.; Fujimura, H. \& Kume, T. (2002b). Tissue-specific regulation of expression and activity of P-glycoprotein in adjuvant arthritis rats. Eur J Pharm Sci 16 29-36.

Achira, M.; Totsuka, R. \& Kume, T. (2002c). Decreased activity of hepatic P-glycoprotein in the isolated perfused liver of the adjuvant arthritis rat. Xenobiotica 32 963-973. 
Achira, M.; Totsuka, R. \& Kume, T. (2002d). Differences in pharmacokinetics and hepatobiliary transport of a novel anti-inflammatory agent between normal and adjuvant arthritis rats. Xenobiotica 32 1139-1149.

Adam-Stitah, S.; Penna, L.; Chambon, P. \& Rochette-Egly, C. (1999). Hyperphosphorylation of the retinoid $\mathrm{X}$ receptor alpha by activated c-Jun NH2-terminal kinases. J Biol Chem 274 18932-18941.

Aguirre, C.; Troconiz, I. F.; Valdivieso, A.; Jimenez, R. M.; Gonzalez, J. P.; Calvo, R. \& Rodriguez-Sasiain, J. M. (1996). Pharmacokinetics and pharmacodynamics of penbutolol in healthy and cancer subjects: role of altered protein binding. Res Commun Mol Pathol Pharmacol 92 53-72.

Aitken, A. E.; Richardson, T. A. \& Morgan, E. T. (2006). Regulation of drug-metabolizing enzymes and transporters in inflammation. Annu Rev Pharmacol Toxicol 46 123-149.

Aliprantis, A. O.; Yang, R. B.; Mark, M. R.; Suggett, S.; Devaux, B.; Radolf, J. D.; Klimpel, G. R.; Godowski, P. \& Zychlinsky, A. (1999). Cell activation and apoptosis by bacterial lipoproteins through toll-like receptor-2. Science 285 736-739.

Alkayed, N. J.; Goyagi, T.; Joh, H. D.; Klaus, J.; Harder, D. R.; Traystman, R. J. \& Hurn, P. D. (2002). Neuroprotection and P450 2C11 upregulation after experimental transient ischemic attack. Stroke 33 1677-1684.

Arinc, E.; Arslan, S. \& Adali, O. (2005). Differential effects of diabetes on CYP2E1 and CYP2B4 proteins and associated drug metabolizing enzyme activities in rabbit liver. Arch Toxicol 79 427-433.

Baek, H. W.; Bae, S. K.; Lee, M. G. \& Sohn, Y. T. (2006). Pharmacokinetics of chlorzoxazone in rats with diabetes: Induction of CYP2E1 on 6-hydroxychlorzoxazone formation. J Pharm Sci 95 2452-2462.

Balkwill, F. \& Mantovani, A. (2001). Inflammation and cancer: back to Virchow? Lancet 357 539-545.

Barker, C. W.; Fagan, J. B. \& Pasco, D. S. (1992). Interleukin-1 beta suppresses the induction of P4501A1 and P4501A2 mRNAs in isolated hepatocytes. J Biol Chem 267 80508055.

Barshop, N. J.; Capparelli, E. V.; Sirlin, C. B.; Schwimmer, J. B. \& Lavine, J. E. (2011). Acetaminophen pharmacokinetics in children with nonalcoholic fatty liver disease. J Pediatr Gastroenterol Nutr 52 198-202.

Bica, I.; McGovern, B.; Dhar, R.; Stone, D.; McGowan, K.; Scheib, R. \& Snydman, D. R. (2001). Increasing mortality due to end-stage liver disease in patients with human immunodeficiency virus infection. Clin Infect Dis 32 492-497.

Burke, F. \& Balkwill, F. R. (1996). Cytokines in animal models of cancer. Biotherapy 8 229-241.

Burke, F.; Relf, M.; Negus, R. \& Balkwill, F. (1996). A cytokine profile of normal and malignant ovary. Cytokine 8 578-585.

Callahan, S. M.; Ming, X.; Lu, S. K.; Brunner, L. J. \& Croyle, M. A. (2005). Considerations for use of recombinant adenoviral vectors: dose effect on hepatic cytochromes P450. J Pharmacol Exp Ther 312 492-501.

Carlson, T. J. \& Billings, R. E. (1996). Role of nitric oxide in the cytokine-mediated regulation of cytochrome P-450. Mol Pharmacol 49 796-801.

Chaluvadi, M. R.; Kinloch, R. D.; Nyagode, B. A.; Richardson, T. A.; Raynor, M. J.; Sherman, M.; Antonovic, L.; Strobel, H. W.; Dillehay, D. L. \& Morgan, E. T. (2009). Regulation of hepatic cytochrome P450 expression in mice with intestinal or systemic infections of citrobacter rodentium. Drug Metab Dispos 37 366-374. 
Chang, K. C.; Bell, T. D.; Lauer, B. A. \& Chai, H. (1978). Altered theophylline pharmacokinetics during acute respiratory viral illness. Lancet 1 1132-1133.

Charles, K. A.; Rivory, L. P.; Brown, S. L.; Liddle, C.; Clarke, S. J. \& Robertson, G. R. (2006). Transcriptional repression of hepatic cytochrome P450 3A4 gene in the presence of cancer. Clin Cancer Res 12 7492-7497.

Chen, T. L.; Chen, S. H.; Tai, T. Y.; Chao, C. C.; Park, S. S.; Guengerich, F. P. \& Ueng, T. H. (1996). Induction and suppression of renal and hepatic cytochrome P450-dependent monooxygenases by acute and chronic streptozotocin diabetes in hamsters. Arch Toxicol 70 202-208.

Chen, Y.; Ferguson, S. S.; Negishi, M. \& Goldstein, J. A. (2004). Induction of human CYP2C9 by rifampicin, hyperforin, and phenobarbital is mediated by the pregnane $X$ receptor. J Pharmacol Exp Ther 308 495-501.

Cheng, Q.; Aleksunes, L. M.; Manautou, J. E.; Cherrington, N. J.; Scheffer, G. L.; Yamasaki, H. \& Slitt, A. L. (2008). Drug-metabolizing enzyme and transporter expression in a mouse model of diabetes and obesity. Mol Pharm 5 77-91.

Chua, S. C., Jr.; White, D. W.; Wu-Peng, X. S.; Liu, S. M.; Okada, N.; Kershaw, E. E.; Chung, W. K.; Power-Kehoe, L.; Chua, M.; Tartaglia, L. A. \& Leibel, R. L. (1996). Phenotype of fatty due to Gln269Pro mutation in the leptin receptor (Lepr). Diabetes 451141 1143.

Corbett, T. H. \& Nettesheim, P. (1973). Effect of PR-8 viral respiratory infection of benz[a]pyrene hydroxylase activity in BALB/c mice. J Natl Cancer Inst 50 779-782.

De Waziers, I.; Garlatti, M.; Bouguet, J.; Beaune, P. H. \& Barouki, R. (1995). Insulin downregulates cytochrome $\mathrm{P} 450 \mathrm{2B}$ and $2 \mathrm{E}$ expression at the post-transcriptional level in the rat hepatoma cell line. Mol Pharmacol 47 474-479.

DeLoia, J. A.; Zamboni, W. C.; Jones, J. M.; Strychor, S.; Kelley, J. L. \& Gallion, H. H. (2008). Expression and activity of taxane-metabolizing enzymes in ovarian tumors. Gynecol Oncol 108 355-360.

Deng, X.; Luyendyk, J. P.; Ganey, P. E. \& Roth, R. A. (2009). Inflammatory stress and idiosyncratic hepatotoxicity: hints from animal models. Pharmacol Rev 61 262-282.

Derry, C. L.; Kroboth, P. D.; Pittenger, A. L.; Kroboth, F. J.; Corey, S. E. \& Smith, R. B. (1995). Pharmacokinetics and pharmacodynamics of triazolam after two intermittent doses in obese and normal-weight men. J Clin Psychopharmacol 15 197-205.

Diao, L.; Li, N.; Brayman, T. G.; Hotz, K. J. \& Lai, Y. (2010). Regulation of MRP2/ ABCC2 and BSEP/ABCB11 expression in sandwich cultured human and rat hepatocytes exposed to inflammatory cytokines TNF-\{alpha\}, IL-6, and IL-1\{beta\}. J Biol Chem 285 31185-31192.

Dietrich, C. G.; de Waart, D. R.; Ottenhoff, R.; Schoots, I. G. \& Elferink, R. P. (2001). Increased bioavailability of the food-derived carcinogen 2-amino-1-methyl-6phenylimidazo[4,5-b]pyridine in MRP2-deficient rats. Mol Pharmacol 59 974-980.

Dipasquale, G.; Welaj, P. \& Rassaert, C. L. (1974). Prolonged pentobarbital sleeping time in adjuvant-induced polyarthritic rats. Res Commun Chem Pathol Pharmacol 9 253-264.

Dixon, R. L.; Hart, L. G. \& Fouts, J. R. (1961). The metabolism of drugs by liver microsomes from alloxan-diabetic rats. J Pharmacol Exp Ther 133 7-11.

Dixon, R. L.; Hart, L. G.; Rogers, L. A. \& Fouts, J. R. (1963). The Metabolism of Drugs by Liver Microsomes from Alloxan-Diabetic Rats: Long Term Diabetes. J Pharmacol Exp Ther 142 312-317. 
Donato, M. T.; Jimenez, N.; Serralta, A.; Mir, J.; Castell, J. V. \& Gomez-Lechon, M. J. (2007). Effects of steatosis on drug-metabolizing capability of primary human hepatocytes. Toxicol In Vitro 21 271-276.

Donato, M. T.; Lahoz, A.; Jimenez, N.; Perez, G.; Serralta, A.; Mir, J.; Castell, J. V. \& GomezLechon, M. J. (2006). Potential impact of steatosis on cytochrome P450 enzymes of human hepatocytes isolated from fatty liver grafts. Drug Metab Dispos 34 1556-1562.

Ferrari, L.; Peng, N.; Halpert, J. R. \& Morgan, E. T. (2001). Role of nitric oxide in downregulation of CYP2B1 protein, but not RNA, in primary cultures of rat hepatocytes. Mol Pharmacol 60 209-216.

Fisher, C. D.; Jackson, J. P.; Lickteig, A. J.; Augustine, L. M. \& Cherrington, N. J. (2008). Drug metabolizing enzyme induction pathways in experimental non-alcoholic steatohepatitis. Arch Toxicol 82 959-964.

Fisher, C. D.; Lickteig, A. J.; Augustine, L. M.; Oude Elferink, R. P.; Besselsen, D. G.; Erickson, R. P. \& Cherrington, N. J. (2009a). Experimental non-alcoholic fatty liver disease results in decreased hepatic uptake transporter expression and function in rats. Eur J Pharmacol 613 119-127.

Fisher, C. D.; Lickteig, A. J.; Augustine, L. M.; Ranger-Moore, J.; Jackson, J. P.; Ferguson, S. S. \& Cherrington, N. J. (2009b). Hepatic cytochrome P450 enzyme alterations in humans with progressive stages of nonalcoholic fatty liver disease. Drug Metab Dispos 37 2087-2094.

Fisher, R. A.; Bu, D.; Thompson, M.; Wolfe, L. \& Ritter, J. K. (2004). Optimization of conditions for clinical human hepatocyte infusion. Cell Transplant 13 677-689.

Fliser, D.; Buchholz, K. \& Haller, H. (2004). Antiinflammatory effects of angiotensin II subtype 1 receptor blockade in hypertensive patients with microinflammation. Circulation 110 1103-1107.

Frapolli, R.; Zucchetti, M.; Sessa, C.; Marsoni, S.; Vigano, L.; Locatelli, A.; Rulli, E.; Compagnoni, A.; Bello, E.; Pisano, C.; Carminati, P. \& D'Incalci, M. (2010). Clinical pharmacokinetics of the new oral camptothecin gimatecan: the inter-patient variability is related to alpha1-acid glycoprotein plasma levels. Eur J Cancer 46505 516.

Frye, R. F.; Schneider, V. M.; Frye, C. S. \& Feldman, A. M. (2002). Plasma levels of TNFalpha and IL-6 are inversely related to cytochrome P450-dependent drug metabolism in patients with congestive heart failure. J Card Fail 8 315-319.

Garcia Del Busto Cano, E. \& Renton, K. W. (2003). Modulation of hepatic cytochrome P450 during Listeria monocytogenes infection of the brain. J Pharm Sci 92 1860-1868.

Ghose, R.; Guo, T. \& Haque, N. (2009). Regulation of gene expression of hepatic drug metabolizing enzymes and transporters by the Toll-like receptor 2 ligand, lipoteichoic acid. Arch Biochem Biophys 481 123-130.

Ghose, R.; Guo, T.; Vallejo, J. G. \& Gandhi, A. (2011a). Differential role of Toll-interleukin 1 receptor domain-containing adaptor protein in Toll-like receptor 2-mediated regulation of gene expression of hepatic cytokines and drug-metabolizing enzymes. Drug Metab Dispos 39 874-881.

Ghose, R.; Omoluabi, O.; Gandhi, A.; Shah, P.; Strohacker, K.; Carpenter, K. C.; McFarlin, B. \& Guo, T. (2011b). Role of high-fat diet in regulation of gene expression of drug metabolizing enzymes and transporters. Life Sci 89 57-64.

Ghose, R.; White, D.; Guo, T.; Vallejo, J. \& Karpen, S. J. (2008). Regulation of hepatic drugmetabolizing enzyme genes by Toll-like receptor 4 signaling is independent of Toll- 
interleukin 1 receptor domain-containing adaptor protein. Drug Metab Dispos 36 95101.

Ghose, R.; Zimmerman, T. L.; Thevananther, S. \& Karpen, S. J. (2004). Endotoxin leads to rapid subcellular re-localization of hepatic RXRalpha: A novel mechanism for reduced hepatic gene expression in inflammation. Nucl Recept 24.

Gilmore, T. D. (2006). Introduction to NF-kappaB: players, pathways, perspectives. Oncogene 25 6680-6684.

Ginsburg, I. (2002). Role of lipoteichoic acid in infection and inflammation. Lancet Infect Dis 2 171-179.

Giraud, C.; Manceau, S.; Decleves, X.; Goffinet, F.; Morini, J. P.; Chappuy, H.; Batteux, F.; Chouzenoux, S.; Yousif, S.; Scherrmann, J. M.; Blanche, S. \& Treluyer, J. M. (2010). Influence of development, HIV infection, and antiretroviral therapies on the gene expression profiles of $\mathrm{ABC}$ transporters in human lymphocytes. J Clin Pharmacol 50 226-230.

Godellas, C. V.; Williams, J. F. \& Fabri, P. J. (1995). Mixed-function oxidase activity in sepsis. J Surg Res 59 783-786.

Gomez-Lechon, M. J.; Donato, M. T.; Castell, J. V. \& Jover, R. (2004). Human hepatocytes in primary culture: the choice to investigate drug metabolism in man. Curr Drug Metab 5 443-462.

Gonzalez, F. J. \& Lee, Y. H. (1996). Constitutive expression of hepatic cytochrome P450 genes. Faseb J 10 1112-1117.

Goodwin, B.; Hodgson, E.; D'Costa, D. J.; Robertson, G. R. \& Liddle, C. (2002). Transcriptional regulation of the human CYP3A4 gene by the constitutive androstane receptor. Mol Pharmacol 62 359-365.

Goodwin, S. D.; Gallis, H. A.; Chow, A. T.; Wong, F. A.; Flor, S. C. \& Bartlett, J. A. (1994). Pharmacokinetics and safety of levofloxacin in patients with human immunodeficiency virus infection. Antimicrob Agents Chemother 38 799-804.

Goralski, K. B.; Abdulla, D.; Sinal, C. J.; Arsenault, A. \& Renton, K. W. (2005). Toll-like receptor-4 regulation of hepatic Cyp3a11 metabolism in a mouse model of LPSinduced CNS inflammation. Am J Physiol Gastrointest Liver Physiol 289 G434-443.

Goralski, K. B.; Hartmann, G.; Piquette-Miller, M. \& Renton, K. W. (2003). Downregulation of mdr1a expression in the brain and liver during CNS inflammation alters the in vivo disposition of digoxin. Br J Pharmacol 139 35-48.

Gous, A. G.; Dance, M. D.; Lipman, J.; Luyt, D. K.; Mathivha, R. \& Scribante, J. (1995). Changes in vancomycin pharmacokinetics in critically ill infants. Anaesth Intensive Care 23 678-682.

Gray, J. D.; Renton, K. W. \& Hung, O. R. (1983). Depression of theophylline elimination following BCG vaccination. Br J Clin Pharmacol 16 735-737.

Grube, M.; Ameling, S.; Noutsias, M.; Kock, K.; Triebel, I.; Bonitz, K.; Meissner, K.; Jedlitschky, G.; Herda, L. R.; Reinthaler, M.; Rohde, M.; Hoffmann, W.; Kuhl, U.; Schultheiss, H. P.; Volker, U.; Felix, S. B.; Klingel, K.; Kandolf, R. \& Kroemer, H. K. (2011). Selective regulation of cardiac organic cation transporter novel type 2 (OCTN2) in dilated cardiomyopathy. Am J Pathol 178 2547-2559.

Gu, X.; Ke, S.; Liu, D.; Sheng, T.; Thomas, P. E.; Rabson, A. B.; Gallo, M. A.; Xie, W. \& Tian, Y. (2006). Role of NF-kappaB in regulation of PXR-mediated gene expression: a mechanism for the suppression of cytochrome P-450 3A4 by proinflammatory agents. J Biol Chem 281 17882-17889. 
Guengerich, F. P. (1999). Cytochrome P-450 3A4: regulation and role in drug metabolism. Annu Rev Pharmacol Toxicol 39 1-17.

Guirguis, M. S. \& Jamali, F. (2003). Disease-drug interaction: Reduced response to propranolol despite increased concentration in the rat with inflammation. J Pharm Sci 92 1077-1084.

Handel, M. L.; McMorrow, L. B. \& Gravallese, E. M. (1995). Nuclear factor-kappa B in rheumatoid synovium. Localization of p50 and p65. Arthritis Rheum 38 1762-1770.

Hardwick, R. N.; Fisher, C. D.; Canet, M. J.; Lake, A. D. \& Cherrington, N. J. (2010). Diversity in antioxidant response enzymes in progressive stages of human nonalcoholic fatty liver disease. Drug Metab Dispos 38 2293-2301.

Harris, M. (1980). Careers in nursing: caring for children with rheumatoid arthritis. Nursing (Lond) 880-881.

Hartmann, G.; Kim, H. \& Piquette-Miller, M. (2001). Regulation of the hepatic multidrug resistance gene expression by endotoxin and inflammatory cytokines in mice. Int Immunopharmacol 1 189-199.

Hartmann, G.; Vassileva, V. \& Piquette-Miller, M. (2005). Impact of endotoxin-induced changes in P-glycoprotein expression on disposition of doxorubicin in mice. Drug Metab Dispos 33 820-828.

Hasegawa, T.; Nadai, M.; Wang, L.; Haghgoo, S.; Nabeshima, T. \& Kato, N. (1994). Influence of endotoxin and lipid A on the renal handling and accumulation of gentamicin in rats. Biol Pharm Bull 17 1651-1655.

Higgins, L. M.; Frankel, G.; Douce, G.; Dougan, G. \& MacDonald, T. T. (1999). Citrobacter rodentium infection in mice elicits a mucosal Th1 cytokine response and lesions similar to those in murine inflammatory bowel disease. Infect Immun 67 3031-3039.

Hoffmeyer, S.; Burk, O.; von Richter, O.; Arnold, H. P.; Brockmoller, J.; Johne, A.; Cascorbi, I.; Gerloff, T.; Roots, I.; Eichelbaum, M. \& Brinkmann, U. (2000). Functional polymorphisms of the human multidrug-resistance gene: multiple sequence variations and correlation of one allele with P-glycoprotein expression and activity in vivo. Proc Natl Acad Sci U S A 97 3473-3478.

Hotamisligil, G. S.; Shargill, N. S. \& Spiegelman, B. M. (1993). Adipose expression of tumor necrosis factor-alpha: direct role in obesity-linked insulin resistance. Science $25987-$ 91.

Ishikawa, M.; Ohzeki, R.; Takayanagi, Y. \& Sasaki, K. (1990). Potentiation of cisplatin lethality by bacterial lipopolysaccharide pretreatment in mice. Res Commun Chem Pathol Pharmacol 70 375-378.

Jancova, P.; Anzenbacher, P. \& Anzenbacherova, E. (2010). Phase II drug metabolizing enzymes. Biomed Pap Med Fac Univ Palacky Olomouc Czech Repub 154 103-116.

Johnston, S. C. (2004). Ischemic preconditioning from transient ischemic attacks? Data from the Northern California TIA Study. Stroke 35 2680-2682.

Kacevska, M.; Downes, M. R.; Sharma, R.; Evans, R. M.; Clarke, S. J.; Liddle, C. \& Robertson, G. R. (2011). Extrahepatic cancer suppresses nuclear receptor-regulated drug metabolism. Clin Cancer Res 17 3170-3180.

Kagan, J. C. \& Medzhitov, R. (2006). Phosphoinositide-mediated adaptor recruitment controls Toll-like receptor signaling. Cell 125 943-955.

Karin, M.; Cao, Y.; Greten, F. R. \& Li, Z. W. (2002). NF-kappaB in cancer: from innocent bystander to major culprit. Nat Rev Cancer 2 301-310. 
Kast, H. R.; Goodwin, B.; Tarr, P. T.; Jones, S. A.; Anisfeld, A. M.; Stoltz, C. M.; Tontonoz, P.; Kliewer, S.; Willson, T. M. \& Edwards, P. A. (2002). Regulation of multidrug resistance-associated protein 2 (ABCC2) by the nuclear receptors pregnane $X$ receptor, farnesoid X-activated receptor, and constitutive androstane receptor. J Biol Chem 277 2908-2915.

Kato, R. (1977). Drug metabolism under pathological and abnormal physiological states in animals and man. Xenobiotica 7 25-92.

Kato, R.; Frontino, G. \& Vassanellip (1963). Decreased activities of liver microsomal drugmetabolizing enzymes in the rats bearing Walker carcinosarcoma. Experientia 19 3132.

Kato, R.; Takanaka, A. \& Oshima, T. (1968). Drug metabolism in tumor-bearing rats. II. In vivo metabolisms and effects of drugs in tumor-bearing rats. Jpn J Pharmacol 18245 254.

Kawase, A.; Tsunokuni, Y. \& Iwaki, M. (2007a). Effects of alterations in CAR on bilirubin detoxification in mouse collagen-induced arthritis. Drug Metab Dispos 35 256-261.

Kawase, A.; Yoshida, I.; Tsunokuni, Y. \& Iwaki, M. (2007b). Decreased PXR and CAR inhibit transporter and CYP mRNA Levels in the liver and intestine of mice with collageninduced arthritis. Xenobiotica 37 366-374.

Ke, S.; Rabson, A. B.; Germino, J. F.; Gallo, M. A. \& Tian, Y. (2001). Mechanism of suppression of cytochrome P-450 1A1 expression by tumor necrosis factor-alpha and lipopolysaccharide. J Biol Chem 276 39638-39644.

Kikuchi, R.; McCown, M.; Olson, P.; Tateno, C.; Morikawa, Y.; Katoh, Y.; Bourdet, D. L.; Monshouwer, M. \& Fretland, A. J. (2010). Effect of hepatitis C virus infection on the mRNA expression of drug transporters and cytochrome p450 enzymes in chimeric mice with humanized liver. Drug Metab Dispos 38 1954-1961.

Kim, S. J.; Kang, H. S.; Jung, S. Y.; Min, S. Y.; Lee, S.; Kim, S. W.; Kwon, Y.; Lee, K. S.; Shin, K. H. \& Ro, J. (2010). Methylation patterns of genes coding for drug-metabolizing enzymes in tamoxifen-resistant breast cancer tissues. J Mol Med (Berl) 88 1123-1131.

Kim, S. K.; Abdelmegeed, M. A. \& Novak, R. F. (2006). Identification of the insulin signaling cascade in the regulation of alpha-class glutathione S-transferase expression in primary cultured rat hepatocytes. J Pharmacol Exp Ther 316 1255-1261.

Kim, S. K. \& Novak, R. F. (2007). The role of intracellular signaling in insulin-mediated regulation of drug metabolizing enzyme gene and protein expression. Pharmacol Ther 113 88-120.

Kim, Y. C.; Lee, A. K.; Lee, J. H.; Lee, I.; Lee, D. C.; Kim, S. H.; Kim, S. G. \& Lee, M. G. (2005a). Pharmacokinetics of theophylline in diabetes mellitus rats: induction of CYP1A2 and CYP2E1 on 1,3-dimethyluric acid formation. Eur J Pharm Sci 26 114123.

Kim, Y. C.; Lee, J. H.; Kim, S. H. \& Lee, M. G. (2005b). Effect of CYP3A1(23) induction on clarithromycin pharmacokinetics in rats with diabetes mellitus. Antimicrob Agents Chemother 49 2528-2532.

Kinloch, R. D.; Lee, C. M.; van Rooijen, N. \& Morgan, E. T. (2011). Selective role for tumor necrosis factor-alpha, but not interleukin-1 or Kupffer cells, in down-regulation of CYP3A11 and CYP3A25 in livers of mice infected with a noninvasive intestinal pathogen. Biochem Pharmacol 82 312-321.

Kivisto, K. T.; Niemi, M.; Schaeffeler, E.; Pitkala, K.; Tilvis, R.; Fromm, M. F.; Schwab, M.; Lang, F.; Eichelbaum, M. \& Strandberg, T. (2005). CYP3A5 genotype is associated 
with diagnosis of hypertension in elderly patients: data from the DEBATE Study. Am J Pharmacogenomics 5 191-195.

Klotz, U.; McHorse, T. S.; Wilkinson, G. R. \& Schenker, S. (1974). The effect of cirrhosis on the disposition and elimination of meperidine in man. Clin Pharmacol Ther 16 667675.

Kraemer, M. J.; Furukawa, C. T.; Koup, J. R.; Shapiro, G. G.; Pierson, W. E. \& Bierman, C. W. (1982). Altered theophylline clearance during an influenza B outbreak. Pediatrics 69 476-480.

Kulmatycki, K. M.; Abouchehade, K.; Sattari, S. \& Jamali, F. (2001). Drug-disease interactions: reduced beta-adrenergic and potassium channel antagonist activities of sotalol in the presence of acute and chronic inflammatory conditions in the rat. Br J Pharmacol 133 286-294.

Laporte, J. D.; Moore, P. E.; Panettieri, R. A.; Moeller, W.; Heyder, J. \& Shore, S. A. (1998). Prostanoids mediate IL-1beta-induced beta-adrenergic hyporesponsiveness in human airway smooth muscle cells. Am J Physiol 275 L491-501.

Lazarou, J.; Pomeranz, B. H. \& Corey, P. N. (1998). Incidence of adverse drug reactions in hospitalized patients: a meta-analysis of prospective studies. Jama 279 1200-1205.

Le, H. T.; Boquet, M. P.; Clark, E. A.; Callahan, S. M. \& Croyle, M. A. (2006). Renal pathophysiology after systemic administration of recombinant adenovirus: changes in renal cytochromes P450 based on vector dose. Hum Gene Ther 17 1095-1111.

Le Vee, M.; Gripon, P.; Stieger, B. \& Fardel, O. (2008). Down-regulation of organic anion transporter expression in human hepatocytes exposed to the proinflammatory cytokine interleukin 1beta. Drug Metab Dispos 36 217-222.

Lee, B. L.; Wong, D.; Benowitz, N. L. \& Sullam, P. M. (1993). Altered patterns of drug metabolism in patients with acquired immunodeficiency syndrome. Clin Pharmacol Ther 53 529-535.

Lee, G. \& Piquette-Miller, M. (2003). Cytokines alter the expression and activity of the multidrug resistance transporters in human hepatoma cell lines; analysis using RTPCR and cDNA microarrays. J Pharm Sci 92 2152-2163.

Lee, G. H.; Proenca, R.; Montez, J. M.; Carroll, K. M.; Darvishzadeh, J. G.; Lee, J. I. \& Friedman, J. M. (1996). Abnormal splicing of the leptin receptor in diabetic mice. Nature 379 632-635.

Leemans, J. C.; Vervoordeldonk, M. J.; Florquin, S.; van Kessel, K. P. \& van der Poll, T. (2002). Differential role of interleukin-6 in lung inflammation induced by lipoteichoic acid and peptidoglycan from Staphylococcus aureus. Am J Respir Crit Care Med 165 1445-1450.

Lickteig, A. J.; Fisher, C. D.; Augustine, L. M.; Aleksunes, L. M.; Besselsen, D. G.; Slitt, A. L.; Manautou, J. E. \& Cherrington, N. J. (2007a). Efflux transporter expression and acetaminophen metabolite excretion are altered in rodent models of nonalcoholic fatty liver disease. Drug Metab Dispos 35 1970-1978.

Lickteig, A. J.; Fisher, C. D.; Augustine, L. M. \& Cherrington, N. J. (2007b). Genes of the antioxidant response undergo upregulation in a rodent model of nonalcoholic steatohepatitis. J Biochem Mol Toxicol 21 216-220.

Lind, D. S.; Hochwald, S. N.; Malaty, J.; Rekkas, S.; Hebig, P.; Mishra, G.; Moldawer, L. L.; Copeland, E. M., 3rd \& Mackay, S. (2001). Nuclear factor-kappa B is upregulated in colorectal cancer. Surgery 130 363-369. 
Lucas, D.; Farez, C.; Bardou, L. G.; Vaisse, J.; Attali, J. R. \& Valensi, P. (1998). Cytochrome P450 2E1 activity in diabetic and obese patients as assessed by chlorzoxazone hydroxylation. Fundam Clin Pharmacol 12 553-558.

Maddox, J. F.; Amuzie, C. J.; Li, M.; Newport, S. W.; Sparkenbaugh, E.; Cuff, C. F.; Pestka, J. J.; Cantor, G. H.; Roth, R. A. \& Ganey, P. E. (2010). Bacterial- and viral-induced inflammation increases sensitivity to acetaminophen hepatotoxicity. J Toxicol Environ Health A 73 58-73.

Mannering, G. J. \& Deloria, L. B. (1986). The pharmacology and toxicology of the interferons: an overview. Annu Rev Pharmacol Toxicol 26 455-515.

Martin, G. S.; Mannino, D. M.; Eaton, S. \& Moss, M. (2003). The epidemiology of sepsis in the United States from 1979 through 2000. N Engl J Med 348 1546-1554.

Mayo, P. R.; Skeith, K.; Russell, A. S. \& Jamali, F. (2000). Decreased dromotropic response to verapamil despite pronounced increased drug concentration in rheumatoid arthritis. Br J Clin Pharmacol 50 605-613.

McHorse, T. S.; Klotz, U.; Wilkinson, G. \& Schenker, S. (1974). Impaired elimination of meperidine in patients with liver disease. Trans Assoc Am Physicians 87 281-287.

Meyer, U. A. (1996). Overview of enzymes of drug metabolism. J Pharmacokinet Biopharm 24 449-459.

Milosevic, N.; Schawalder, H. \& Maier, P. (1999). Kupffer cell-mediated differential downregulation of cytochrome P450 metabolism in rat hepatocytes. Eur J Pharmacol 368 75-87.

Mizuno, N.; Niwa, T.; Yotsumoto, Y. \& Sugiyama, Y. (2003). Impact of drug transporter studies on drug discovery and development. Pharmacol Rev 55 425-461.

Mizuno, N. \& Sugiyama, Y. (2002). Drug transporters: their role and importance in the selection and development of new drugs. Drug Metab Pharmacokinet 17 93-108.

Modric, S.; Webb, A. I. \& Derendorf, H. (1998). Pharmacokinetics and pharmacodynamics of tilmicosin in sheep and cattle. J Vet Pharmacol Ther 21 444-452.

Monshouwer, M.; Witkamp, R. F.; Nijmeijer, S. M.; Pijpers, A.; Verheijden, J. H. \& Van Miert, A. S. (1995). Selective effects of a bacterial infection (Actinobacillus pleuropneumoniae) on the hepatic clearances of caffeine, antipyrine, paracetamol, and indocyanine green in the pig. Xenobiotica 25 491-499.

Monshouwer, M.; Witkamp, R. F.; Nujmeijer, S. M.; Van Amsterdam, J. G. \& Van Miert, A. S. (1996). Suppression of cytochrome P450- and UDP glucuronosyl transferasedependent enzyme activities by proinflammatory cytokines and possible role of nitric oxide in primary cultures of pig hepatocytes. Toxicol Appl Pharmacol 137 237244.

Mor, A.; Abramson, S. B. \& Pillinger, M. H. (2005). The fibroblast-like synovial cell in rheumatoid arthritis: a key player in inflammation and joint destruction. Clin Immunol 115 118-128.

Morris, S. M., Jr. \& Billiar, T. R. (1994). New insights into the regulation of inducible nitric oxide synthesis. Am J Physiol 266 E829-839.

Muntane-Relat, J.; Ourlin, J. C.; Domergue, J. \& Maurel, P. (1995). Differential effects of cytokines on the inducible expression of CYP1A1, CYP1A2, and CYP3A4 in human hepatocytes in primary culture. Hepatology 22 1143-1153.

Naylor, M. S.; Stamp, G. W.; Foulkes, W. D.; Eccles, D. \& Balkwill, F. R. (1993). Tumor necrosis factor and its receptors in human ovarian cancer. Potential role in disease progression. J Clin Invest 91 2194-2206. 
Nebert, D. W. \& Russell, D. W. (2002). Clinical importance of the cytochromes P450. Lancet $3601155-1162$.

O'Neill, L. A. \& Bowie, A. G. (2007). The family of five: TIR-domain-containing adaptors in Toll-like receptor signalling. Nat Rev Immunol 7 353-364.

O'Shea, D.; Davis, S. N.; Kim, R. B. \& Wilkinson, G. R. (1994). Effect of fasting and obesity in humans on the 6-hydroxylation of chlorzoxazone: a putative probe of CYP2E1 activity. Clin Pharmacol Ther 56 359-367.

Park, J. H.; Lee, W. I.; Yoon, W. H.; Park, Y. D.; Lee, J. S. \& Lee, M. G. (1998). Pharmacokinetic and pharmacodynamic changes of furosemide after intravenous and oral administration to rats with alloxan-induced diabetes mellitus. Biopharm Drug Dispos 19 357-364.

Park, J. M.; Moon, C. H. \& Lee, M. G. (1996). Pharmacokinetic changes of methotrexate after intravenous administration to streptozotocin-induced diabetes mellitus rats. Res Commun Mol Pathol Pharmacol 93 343-352.

Pascussi, J. M.; Dvorak, Z.; Gerbal-Chaloin, S.; Assenat, E.; Maurel, P. \& Vilarem, M. J. (2003). Pathophysiological factors affecting CAR gene expression. Drug Metab Rev 35 255-268.

Petrovic, V.; Teng, S. \& Piquette-Miller, M. (2007). Regulation of drug transporters during infection and inflammation. Mol Interv 7 99-111.

Petrovic, V. \& Piquette-Miller, M. (2010). Impact of polyinosinic/polycytidylic acid on placental and hepatobiliary drug transporters in pregnant rats. Drug Metab Dispos 38 1760-1766.

Philippe, L.; Gegout-Pottie, P.; Guingamp, C.; Bordji, K.; Terlain, B.; Netter, P. \& Gillet, P. (1997). Relations between functional, inflammatory, and degenerative parameters during adjuvant arthritis in rats. Am J Physiol 273 R1550-1556.

Pinder, M.; Bellomo, R. \& Lipman, J. (2002). Pharmacological principles of antibiotic prescription in the critically ill. Anaesth Intensive Care 30 134-144.

Piquette-Miller, M. \& Jamali, F. (1992). Effect of adjuvant arthritis on the disposition of acebutolol enantiomers in rats. Agents Actions 37 290-296.

Piquette-Miller, M. \& Jamali, F. (1993). Selective effect of adjuvant arthritis on the disposition of propranolol enantiomers in rats detected using a stereospecific HPLC assay. Pharm Res 10 294-299.

Pirmohamed, M.; James, S.; Meakin, S.; Green, C.; Scott, A. K.; Walley, T. J.; Farrar, K.; Park, B. K. \& Breckenridge, A. M. (2004). Adverse drug reactions as cause of admission to hospital: prospective analysis of 18820 patients. Bmj 329 15-19.

Prescott, L. F.; Adjepon-Yamoah, K. K. \& Talbot, R. G. (1976). Impaired Lignocaine metabolism in patients with myocardial infarction and cardiac failure. Br Med J 1 939-941.

Projean, D.; Dautrey, S.; Vu, H. K.; Groblewski, T.; Brazier, J. L. \& Ducharme, J. (2005). Selective downregulation of hepatic cytochrome P450 expression and activity in a rat model of inflammatory pain. Pharm Res 22 62-70.

Regazzi, M.; Maserati, R.; Villani, P.; Cusato, M.; Zucchi, P.; Briganti, E.; Roda, R.; Sacchelli, L.; Gatti, F.; Delle Foglie, P.; Nardini, G.; Fabris, P.; Mori, F.; Castelli, P. \& Testa, L. (2005). Clinical pharmacokinetics of nelfinavir and its metabolite M8 in human immunodeficiency virus (HIV)-positive and HIV-hepatitis C virus-coinfected subjects. Antimicrob Agents Chemother 49 643-649. 
Renton, K. W. (1981). Depression of hepatic cytochrome P-450-dependent mixed function oxidases during infection with encephalomyocarditis virus. Biochem Pharmacol 30 2333-2336.

Reynaert, H.; Geerts, A. \& Henrion, J. (2005). Review article: the treatment of non-alcoholic steatohepatitis with thiazolidinediones. Aliment Pharmacol Ther 22 897-905.

Richardson, T. A. \& Morgan, E. T. (2005). Hepatic cytochrome P450 gene regulation during endotoxin-induced inflammation in nuclear receptor knockout mice. J Pharmacol Exp Ther 314 703-709.

Robinson, L. J.; Roberts, W. K.; Ling, T. T.; Lamming, D.; Sternberg, S. S. \& Roepe, P. D. (1997). Human MDR 1 protein overexpression delays the apoptotic cascade in Chinese hamster ovary fibroblasts. Biochemistry 36 11169-11178.

Ronaldson, P. T. \& Bendayan, R. (2006). HIV-1 viral envelope glycoprotein gp120 triggers an inflammatory response in cultured rat astrocytes and regulates the functional expression of P-glycoprotein. Mol Pharmacol 70 1087-1098.

Rosso, R.; Dolfini, E. \& Donelli, M. G. (1968). Prolonged effect of pentobarbital in tumor bearing rats. Eur J Cancer 4 133-135.

Rosso, R.; Donelli, M. G.; Franchi, G. \& Garattini, S. (1971). Impairement of drug metabolism in tumor-bearing animals. Eur J Cancer 7 565-577.

Sakuma, T.; Honma, R.; Maguchi, S.; Tamaki, H. \& Nemoto, N. (2001). Different expression of hepatic and renal cytochrome P450s between the streptozotocin-induced diabetic mouse and rat. Xenobiotica 31 223-237.

Satoh, M.; Nakamura, M.; Saitoh, H.; Satoh, H.; Akatsu, T.; Iwasaka, J.; Masuda, T. \& Hiramori, K. (2002). Aldosterone synthase (CYP11B2) expression and myocardial fibrosis in the failing human heart. Clin Sci (Lond) 102 381-386.

Sattari, S.; Dryden, W. F.; Eliot, L. A. \& Jamali, F. (2003). Despite increased plasma concentration, inflammation reduces potency of calcium channel antagonists due to lower binding to the rat heart. Br J Pharmacol 139 945-954.

Schoene, B.; Fleischmann, R. A.; Remmer, H. \& von Oldershausen, H. F. (1972). Determination of drug metabolizing enzymes in needle biopsies of human liver. Eur J Clin Pharmacol 4 65-73.

Schrieber, S. J., Wen, Z., Vourvahis, M., Smith, P. C., Fried, M. W., Kashuba, A. D., Hawke, R. L. (2008). The pharmacokinetics of silymarin is altered in patients with hepatitis $\mathrm{C}$ virus and nonalcoholic Fatty liver disease and correlates with plasma caspase3/7 activity. Drug Metab Dispos 36 1909-1916.

Scott, M. J.; Liu, S.; Shapiro, R. A.; Vodovotz, Y. \& Billiar, T. R. (2009). Endotoxin uptake in mouse liver is blocked by endotoxin pretreatment through a suppressor of cytokine signaling-1-dependent mechanism. Hepatology 49 1695-1708.

Sekino, K.; Kubota, T.; Okada, Y.; Yamada, Y.; Yamamoto, K.; Horiuchi, R.; Kimura, K. \& Iga, T. (2003). Effect of the single CYP2C9*3 allele on pharmacokinetics and pharmacodynamics of losartan in healthy Japanese subjects. Eur J Clin Pharmacol 59 589-592.

Sewer, M. B.; Koop, D. R. \& Morgan, E. T. (1996). Endotoxemia in rats is associated with induction of the P4504A subfamily and suppression of several other forms of cytochrome P450. Drug Metab Dispos 24 401-407.

Sewer, M. B. \& Morgan, E. T. (1997). Nitric oxide-independent suppression of P450 2C11 expression by interleukin-1beta and endotoxin in primary rat hepatocytes. Biochem Pharmacol 54 729-737. 
Sharma, R.; Kacevska, M.; London, R.; Clarke, S. J.; Liddle, C. \& Robertson, G. (2008). Downregulation of drug transport and metabolism in mice bearing extra-hepatic malignancies. Br J Cancer 98 91-97.

Shedlofsky, S. I.; Israel, B. C.; McClain, C. J.; Hill, D. B. \& Blouin, R. A. (1994). Endotoxin administration to humans inhibits hepatic cytochrome P450-mediated drug metabolism. J Clin Invest 94 2209-2214.

Shen, G. \& Kong, A. N. (2009). Nrf2 plays an important role in coordinated regulation of Phase II drug metabolism enzymes and Phase III drug transporters. Biopharm Drug Dispos 30 345-355.

Shibata, N.; Shimakawa, H.; Minouchi, T. \& Yamaji, A. (1993). Pharmacokinetics of cyclosporin A after intravenous administration to rats in various disease states. Biol Pharm Bull 16 1130-1135.

Shimamoto, Y.; Kitamura, H.; Hoshi, H.; Kazusaka, A.; Funae, Y.; Imaoka, S.; Saito, M. \& Fujita, S. (1998). Differential alterations in levels of hepatic microsomal cytochrome P450 isozymes following intracerebroventricular injection of bacterial lipopolysaccharide in rats. Arch Toxicol 72 492-498.

Shimojo, N.; Ishizaki, T.; Imaoka, S.; Funae, Y.; Fujii, S. \& Okuda, K. (1993). Changes in amounts of cytochrome P450 isozymes and levels of catalytic activities in hepatic and renal microsomes of rats with streptozocin-induced diabetes. Biochem Pharmacol 46 621-627.

Shore, S. A.; Laporte, J.; Hall, I. P.; Hardy, E. \& Panettieri, R. A., Jr. (1997). Effect of IL-1 beta on responses of cultured human airway smooth muscle cells to bronchodilator agonists. Am J Respir Cell Mol Biol 16 702-712.

Singh, G. \& Renton, K. W. (1981). Interferon-mediated depression of cytochrome P-450dependent drug biotransformation. Mol Pharmacol 20 681-684.

Sonne, J.; Dossing, M.; Loft, S. \& Andreasen, P. B. (1985). Antipyrine clearance in pneumonia. Clin Pharmacol Ther 37 701-704.

Sukhai, M.; Yong, A.; Kalitsky, J. \& Piquette-Miller, M. (2000). Inflammation and interleukin6 mediate reductions in the hepatic expression and transcription of the mdrla and mdr1b Genes. Mol Cell Biol Res Commun 4 248-256.

Synold, T. W.; Dussault, I. \& Forman, B. M. (2001). The orphan nuclear receptor SXR coordinately regulates drug metabolism and efflux. Nat Med 7 584-590.

Takeuchi, O.; Hoshino, K.; Kawai, T.; Sanjo, H.; Takada, H.; Ogawa, T.; Takeda, K. \& Akira, S. (1999). Differential roles of TLR2 and TLR4 in recognition of gram-negative and gram-positive bacterial cell wall components. Immunity 11 443-451.

Tan, F. L.; Moravec, C. S.; Li, J.; Apperson-Hansen, C.; McCarthy, P. M.; Young, J. B. \& Bond, M. (2002). The gene expression fingerprint of human heart failure. Proc Natl Acad Sci U S A 99 11387-11392.

Tantituvanont, A.; Yimprasert, W.; Werawatganone, P. \& Nilubol, D. (2009). Pharmacokinetics of ceftiofur hydrochloride in pigs infected with porcine reproductive and respiratory syndrome virus. J Antimicrob Chemother 63 369-373.

Teng, S. \& Piquette-Miller, M. (2005). The involvement of the pregnane $X$ receptor in hepatic gene regulation during inflammation in mice. J Pharmacol Exp Ther 312 841-848.

Tett, S.; Moore, S. \& Ray, J. (1995). Pharmacokinetics and bioavailability of fluconazole in two groups of males with human immunodeficiency virus (HIV) infection compared with those in a group of males without HIV infection. Antimicrob Agents Chemother 39 1835-1841. 
Thomson, P. D.; Rowland, M. \& Melmon, K. L. (1971). The influence of heart failure, liver disease, and renal failure on the disposition of lidocaine in man. Am Heart J 82 417421.

Thum, T. \& Borlak, J. (2002). Testosterone, cytochrome P450, and cardiac hypertrophy. Faseb J $161537-1549$.

Thummel, K. E. \& Schenkman, J. B. (1990). Effects of testosterone and growth hormone treatment on hepatic microsomal P450 expression in the diabetic rat. Mol Pharmacol 37 119-129.

Tirona, R. G.; Lee, W.; Leake, B. F.; Lan, L. B.; Cline, C. B.; Lamba, V.; Parviz, F.; Duncan, S. A.; Inoue, Y.; Gonzalez, F. J.; Schuetz, E. G. \& Kim, R. B. (2003). The orphan nuclear receptor HNF4alpha determines PXR- and CAR-mediated xenobiotic induction of CYP3A4. Nat Med 9 220-224.

Uno, S.; Kawase, A.; Tsuji, A.; Tanino, T. \& Iwaki, M. (2007). Decreased intestinal CYP3A and P-glycoprotein activities in rats with adjuvant arthritis. Drug Metab Pharmacokinet 22 313-321.

van Waarde, W. M.; Verkade, H. J.; Wolters, H.; Havinga, R.; Baller, J.; Bloks, V.; Muller, M.; Sauer, P. J. \& Kuipers, F. (2002). Differential effects of streptozotocin-induced diabetes on expression of hepatic ABC-transporters in rats. Gastroenterology 122 1842-1852.

Varin, F.; Ducharme, J.; Theoret, Y.; Besner, J. G.; Bevan, D. R. \& Donati, F. (1990). Influence of extreme obesity on the body disposition and neuromuscular blocking effect of atracurium. Clin Pharmacol Ther 48 18-25.

Vee, M. L.; Lecureur, V.; Stieger, B. \& Fardel, O. (2009). Regulation of drug transporter expression in human hepatocytes exposed to the proinflammatory cytokines tumor necrosis factor-alpha or interleukin-6. Drug Metab Dispos 37 685-693.

Veronese, L.; Rautaureau, J.; Sadler, B. M.; Gillotin, C.; Petite, J. P.; Pillegand, B.; Delvaux, M.; Masliah, C.; Fosse, S.; Lou, Y. \& Stein, D. S. (2000). Single-dose pharmacokinetics of amprenavir, a human immunodeficiency virus type 1 protease inhibitor, in subjects with normal or impaired hepatic function. Antimicrob Agents Chemother 44 821-826.

Warren, G. W.; Poloyac, S. M.; Gary, D. S.; Mattson, M. P. \& Blouin, R. A. (1999). Hepatic cytochrome P-450 expression in tumor necrosis factor-alpha receptor (p55/p75) knockout mice after endotoxin administration. J Pharmacol Exp Ther 288 945-950.

Warren, G. W.; van Ess, P. J.; Watson, A. M.; Mattson, M. P. \& Blouin, R. A. (2001). Cytochrome P450 and antioxidant activity in interleukin-6 knockout mice after induction of the acute-phase response. J Interferon Cytokine Res 21 821-826.

Watkins, J. B., 3rd \& Sherman, S. E. (1992). Long-term diabetes alters the hepatobiliary clearance of acetaminophen, bilirubin and digoxin. J Pharmacol Exp Ther 260 1337-1343.

Wellen, K. E. \& Hotamisligil, G. S. (2005). Inflammation, stress, and diabetes. J Clin Invest 115 1111-1119.

Weltman, M. D.; Farrell, G. C.; Hall, P.; Ingelman-Sundberg, M. \& Liddle, C. (1998). Hepatic cytochrome P450 2E1 is increased in patients with nonalcoholic steatohepatitis. Hepatology 27 128-133.

Wichterman, K. A.; Baue, A. E. \& Chaudry, I. H. (1980). Sepsis and septic shock--a review of laboratory models and a proposal. J Surg Res 29 189-201.

Wild, S.; Roglic, G.; Green, A.; Sicree, R. \& King, H. (2004). Global prevalence of diabetes: estimates for the year 2000 and projections for 2030. Diabetes Care 27 1047-1053. 
Wilkinson, G. R. (1997). The effects of diet, aging and disease-states on presystemic elimination and oral drug bioavailability in humans. Adv Drug Deliv Rev 27 129-159.

Williams, J. A. \& Phillips, D. H. (2000). Mammary expression of xenobiotic metabolizing enzymes and their potential role in breast cancer. Cancer Res 60 4667-4677.

Williams, M. L.; Bhargava, P.; Cherrouk, I.; Marshall, J. L.; Flockhart, D. A. \& Wainer, I. W. (2000). A discordance of the cytochrome P450 2C19 genotype and phenotype in patients with advanced cancer. Br J Clin Pharmacol 49 485-488.

Williams, R. O.; Feldmann, M. \& Maini, R. N. (1992). Anti-tumor necrosis factor ameliorates joint disease in murine collagen-induced arthritis. Proc Natl Acad Sci U S A 89 97849788.

Wonganan, P.; Zamboni, W. C.; Strychor, S.; Dekker, J. D. \& Croyle, M. A. (2009). Drug-virus interaction: effect of administration of recombinant adenoviruses on the pharmacokinetics of docetaxel in a rat model. Cancer Gene Ther 16 405-414.

Woodcroft, K. J.; Hafner, M. S. \& Novak, R. F. (2002). Insulin signaling in the transcriptional and posttranscriptional regulation of CYP2E1 expression. Hepatology 35 263-273.

Wyles, D. L. \& Gerber, J. G. (2005). Antiretroviral drug pharmacokinetics in hepatitis with hepatic dysfunction. Clin Infect Dis 40 174-181.

Xie, W. (2008). Nuclear receptors in drug metabolism, John Wiley \& Sons, Inc. ISBN: 978-0-47008679-7, Hoboken, New Jersey.

Xiong, H.; Yoshinari, K.; Brouwer, K. L. \& Negishi, M. (2002). Role of constitutive androstane receptor in the in vivo induction of Mrp3 and CYP2B1/2 by phenobarbital. Drug Metab Dispos 30 918-923.

Yoh, K.; Ishii, G.; Yokose, T.; Minegishi, Y.; Tsuta, K.; Goto, K.; Nishiwaki, Y.; Kodama, T.; Suga, M. \& Ochiai, A. (2004). Breast cancer resistance protein impacts clinical outcome in platinum-based chemotherapy for advanced non-small cell lung cancer. Clin Cancer Res 10 1691-1697.

Yoshinari, K.; Takagi, S.; Sugatani, J. \& Miwa, M. (2006a). Changes in the expression of cytochromes P450 and nuclear receptors in the liver of genetically diabetic $\mathrm{db} / \mathrm{db}$ mice. Biol Pharm Bull 29 1634-1638.

Yoshinari, K.; Takagi, S.; Yoshimasa, T.; Sugatani, J. \& Miwa, M. (2006b). Hepatic CYP3A expression is attenuated in obese mice fed a high-fat diet. Pharm Res 23 1188-1200.

Young, L. C.; Campling, B. G.; Voskoglou-Nomikos, T.; Cole, S. P.; Deeley, R. G. \& Gerlach, J. H. (1999). Expression of multidrug resistance protein-related genes in lung cancer: correlation with drug response. Clin Cancer Res 5 673-680.

Young, M. J.; Clyne, C. D.; Cole, T. J. \& Funder, J. W. (2001). Cardiac steroidogenesis in the normal and failing heart. J Clin Endocrinol Metab 86 5121-5126.

$\mathrm{Yu}, \mathrm{L}$. \& Chen, S. (2008). Toll-like receptors expressed in tumor cells: targets for therapy. Cancer Immunol Immunother 57 1271-1278.

Yu, R.; Lei, W.; Mandlekar, S.; Weber, M. J.; Der, C. J.; Wu, J. \& Kong, A. N. (1999). Role of a mitogen-activated protein kinase pathway in the induction of phase II detoxifying enzymes by chemicals. J Biol Chem 274 27545-27552.

Zhou, J.; Liu, M.; Aneja, R.; Chandra, R.; Lage, H. \& Joshi, H. C. (2006). Reversal of Pglycoprotein-mediated multidrug resistance in cancer cells by the c-Jun NH2terminal kinase. Cancer Res 66 445-452.

Zordoky, B. N. \& El-Kadi, A. O. (2009). Role of NF-kappaB in the regulation of cytochrome P450 enzymes. Curr Drug Metab 10 164-178. 


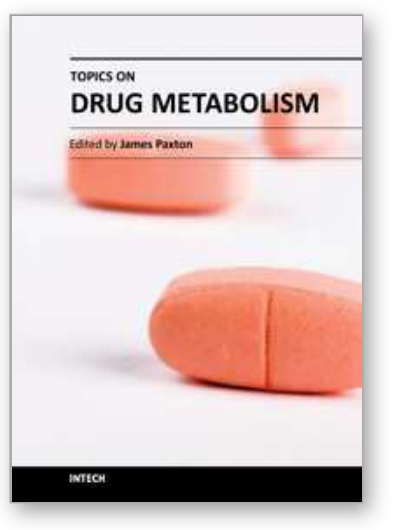

\author{
Topics on Drug Metabolism \\ Edited by Dr. James Paxton
}

ISBN 978-953-51-0099-7

Hard cover, 294 pages

Publisher InTech

Published online 22, February, 2012

Published in print edition February, 2012

In order to avoid late-stage drug failure due to factors such as undesirable metabolic instability, toxic metabolites, drug-drug interactions, and polymorphic metabolism, an enormous amount of effort has been expended by both the pharmaceutical industry and academia towards developing more powerful techniques and screening assays to identify the metabolic profiles and enzymes involved in drug metabolism. This book presents some in-depth reviews of selected topics in drug metabolism. Among the key topics covered are: the interplay between drug transport and metabolism in oral bioavailability; the influence of genetic and epigenetic factors on drug metabolism; impact of disease on transport and metabolism; and the use of novel microdosing techniques and novel LC/MS and genomic technologies to predict the metabolic parameters and profiles of potential new drug candidates.

\title{
How to reference
}

In order to correctly reference this scholarly work, feel free to copy and paste the following:

Adarsh Gandhi and Romi Ghose (2012). Altered Drug Metabolism and Transport in Pathophysiological Conditions, Topics on Drug Metabolism, Dr. James Paxton (Ed.), ISBN: 978-953-51-0099-7, InTech, Available from: http://www.intechopen.com/books/topics-on-drug-metabolism/altered-drug-metabolism-and-transport-inpathophysiological-conditions

\section{INTECH}

open science | open minds

\author{
InTech Europe \\ University Campus STeP Ri \\ Slavka Krautzeka 83/A \\ 51000 Rijeka, Croatia \\ Phone: +385 (51) 770447 \\ Fax: +385 (51) 686166 \\ www.intechopen.com
}

\author{
InTech China \\ Unit 405, Office Block, Hotel Equatorial Shanghai \\ No.65, Yan An Road (West), Shanghai, 200040, China \\ 中国上海市延安西路65号上海国际贵都大饭店办公楼 405 单元 \\ Phone: +86-21-62489820 \\ Fax: +86-21-62489821
}


(C) 2012 The Author(s). Licensee IntechOpen. This is an open access article distributed under the terms of the Creative Commons Attribution 3.0 License, which permits unrestricted use, distribution, and reproduction in any medium, provided the original work is properly cited. 